\title{
ANALISIS KEJADIAN MEDICATION ERROR RESEP PASIEN RAWAT JALAN DI RUMAH SAKIT X CILACAP
}

\author{
Siti Fatimah ${ }^{1}$, Nikmah Nuur Rochmah ${ }^{2 *}$, Yuniariana Pertiwi ${ }^{3}$ \\ ${ }^{1,2,3}$ Program Studi S1 Farmasi STIKES Al-Irsyad Al-Islamiyyah, Cilacap, Jawa Tengah, Indonesia \\ Email correspondence: *nikmah.nuur@gmail.com,
}

\begin{abstract}
ABSTRAK
Kesalahan pengobatan merupakan suatu indikasi tingkat pencapaian keselamatan pasien khususnya terhadap tujuan medikasi yang aman. Medication error banyak terjadi dirumah sakit yang umumnya terjadi pada pengolahan dalam peresepan (prescribing), pembacaan resep (transcribing), penyiapan resep (dispensing), dan administrasi pengobatan (administration). Tujuan dari penelitian ini untuk mengetahui kejadian medication error pada tahap prescribing, transcribing, dispensing dan administration pada pasien rawat jalan di Instalasi Farmasi Rumah Sakit X Cilacap. Penelitian ini merupakan penelitian analitik non-eksperimental terhadap data resep pasien rawat jalan yang ada di Instalasi Farmasi Rumah Sakit X Cilacap. Pengumpulan data dilakukan secara purposive sampling pada bulan Maret 2020. Hasil penelitian menunjukan bahwa medication error yang terjadi di Instalasi Farmasi Rumah Sakit X Cilacap pada tahap prescribing sebesar 30,46\%, transcribing sebesar 11,50\%, dispensing sebesar 25,00\%, dan administration sebesar 1,28\%.
\end{abstract}

Kata kunci: Medication Error, Prescribing, Transcribing, Dispensing, dan Administration.

\begin{abstract}
Medication error is an indication of patient safety achievement rate, especially for the purpose of safe medication. Medication error are often common in hospitals that generally occure in the management of prescribing, transcribing, dispensing, and administration. The purpose of this study to fine out insidance of medication error on the phases of prescribing, transcribing, dispensing, and administration of recipe out patient at $x$ cilacap hospital. This study is a non-eksperimental analytics study to the prescription outpatient data in pharmaceutical of $x$ cilacap hospital. The data were collected purposive sampling on march 2020. The results showed that medication error at recipe outpatient at $x$ cilacap hospital at the phases prescribing of 30,46\%, transcribing 11,50\%, dispensing 25,00\%, and administration 1,28\%.
\end{abstract}

Keywords: Medication Error, Prescribing, Transcribing, Administration and Dispensing

\section{PENDAHULUAN}

Rumah sakit adalah institusi pelayanan kesehatan yang menyelenggarakan pelayanan kesehatan perorangan secara paripurna yang menyediakan pelayanan rawat inap, rawat jalan, dan gawat darurat. Salah satu jenis pelayanan kefarmasian di rumah sakit yaitu pelayanan resep [1]. Setiap rumah sakit mempunyai beberapa kewajiban salah satunya yaitu memberikan informasi yang benar tentang pelayanan rumah sakit kepada pasien[2].

Kesalahan pengobatan (medication error) merupakan suatu indikasi tingkat pencapaian keselamatan pasien (patient safety), khususnya terhadap tujuan tercapainya medikasi yang aman. Medication error adalah kejadian yang dapat dicegah, yang dapat menyebabkan penggunaan obat menjadi tidak tepat atau membahayakan pasien, sementara pengobatannya masih berada dalam kendali tenaga kesehatan, pasien atau konsumen[3]

Merror dapat menyebabkan terjadinya kegagalan terapi bahkan dapat timbul efek obat yang tidak diharapkan, kejadian tersebut dapat merugikan pasien[4]. Kesalahan dalam pemberian obat menduduki peringkat pertama yakni sebanyak $(24,8 \%)$ dari 10 besar insiden yang telah di 
laporkan dan dalam proses penggunaan obat yang meliputi prescribing, transcribing, dispensing, dan administration, dispensing menduduki peringkat pertama. Tingkat terjadinya medication error di Indonesia cukup tinggi. Namun di Indonesia, angka kejadian medication error yang terjadi masih belum terdata secara akurat dan sistematis, tetapi angka kejadian medication error sering kita jumpai di berbagai institusi pelayanan kesehatan di Indonesia[5].

Medication error dapat terjadi pada 4 fase yaitu prescribing error, transcribing error, dispensing error dan administration error. Medication error pada fase prescribing adalah kesalahan yang terjadi pada fase penulisan resep[6]. Hal-hal yang sering terjadi prescribing error adalah penulisan resep yang sulit dibaca dibagian nama obat, satuan numerik obat yang digunakan, bentuk sediaan yang dimaksud, tidak ada dosis sediaan, tidak ada umur pasien, tidak ada nama dokter, tidak ada SIP dokter, tidak ada tanggal pemberian[7].

Pada fase transcribing, kesalahan terjadi pada saat pembacaan resep untuk proses dispensing, antara lain salah membaca resep karena tulisan tidak jelas, informasi tidak jelas atau penggunaan singkatan tidak tepat[5]. Berdasarkan studi dokumentasi dari hasil laporan insiden pada tahap prescribing dimana setelah resep di terima oleh unit farmasi rawat inap maka proses kesalahan yang terjadi adalah pada saat staf farmasi melakukan pembacaan resep dari prescriber (penulis resep)[8].

Dispensing error merupakan ketidaksesuaian antara obat yang diresepkan dengan obat yang diberikan oleh instalasi farmasi kepada pasien atau didistribusikan ke suatu bangsal termasuk pemberian obat dengan kualitas informasi yang rendah[6]. Medication Administration Error (MAE) atau kesalahan administrasi pengobatan didefinisikan sebagai perbedaan antara apa yang diterima oleh pasien dengan apa yang di maksudkan oleh penulis resep[9]. Dari uraian di atas peneliti terdorong untuk melakukan penelitian dengan judul "Analisis Kejadian Medication error Resep Pasien Rawat Jalan Di Rumah Sakit X Cilacap".

\section{METODE PENELITIAN}

\section{Tempat dan Waktu Penelitian}

Penelitian ini telah dilakukan pada bulan Maret 2020 di Instalasi Farmasi Rumah Sakit X Cilacap.

\section{Jenis Penelitian}

Penelitian ini merupakan penelitian analitik non-eksperimental dengan pengumpulan data secara purposive sampling yang didasarkan pada data resep pasien rawat jalan yang ada di Instalasi Farmasi Rumah Sakit X Cilacap.

\section{Populasi dan Sampel Penelitian}

Populasi penelitian ini adalah semua resep pasien rawat jalan yang ada di Instalasi Farmasi Rumah Sakit X Cilacap, pada bulan Januari - Februari 2020 yaitu sebanyak 10.102 resep.

Sampel dalam penelitian ini berupa resep pasien rawat jalan di Instalasi Farmasi Rumah Sakit X Cilacap, dengan metode pengambilan sampel secara random sampling, yang di ambil pada bulan Maret 2020 dan dianggap data telah memenuhi populasi. Perhitungan jumlah minimal sampel yang harus diambil menggunakan metode Slovin dengan Rumus:

$$
n=\frac{N}{1+\left(N\left(e^{2}\right)\right)}
$$

\section{Dimana :}

n : Jumlah sampel

$\mathrm{N} \quad$ : Jumlah populasi

e : Batas toleransi kesalahan pengambilan sampel yang digunakan

Sehingga minimal sampel yang diambil dengan menggunakan rumus di atas yaitu sebanyak 385 .

\section{Variabel Penelitian}



berikut:

Variabel dalam penelitian ini yaitu berupa medication error dengan penjabaran sebagai

Tabel 1. Penjabaran Variabel Penelitian Pada Prescribing, Transcribing, Dispensing dan Aministration

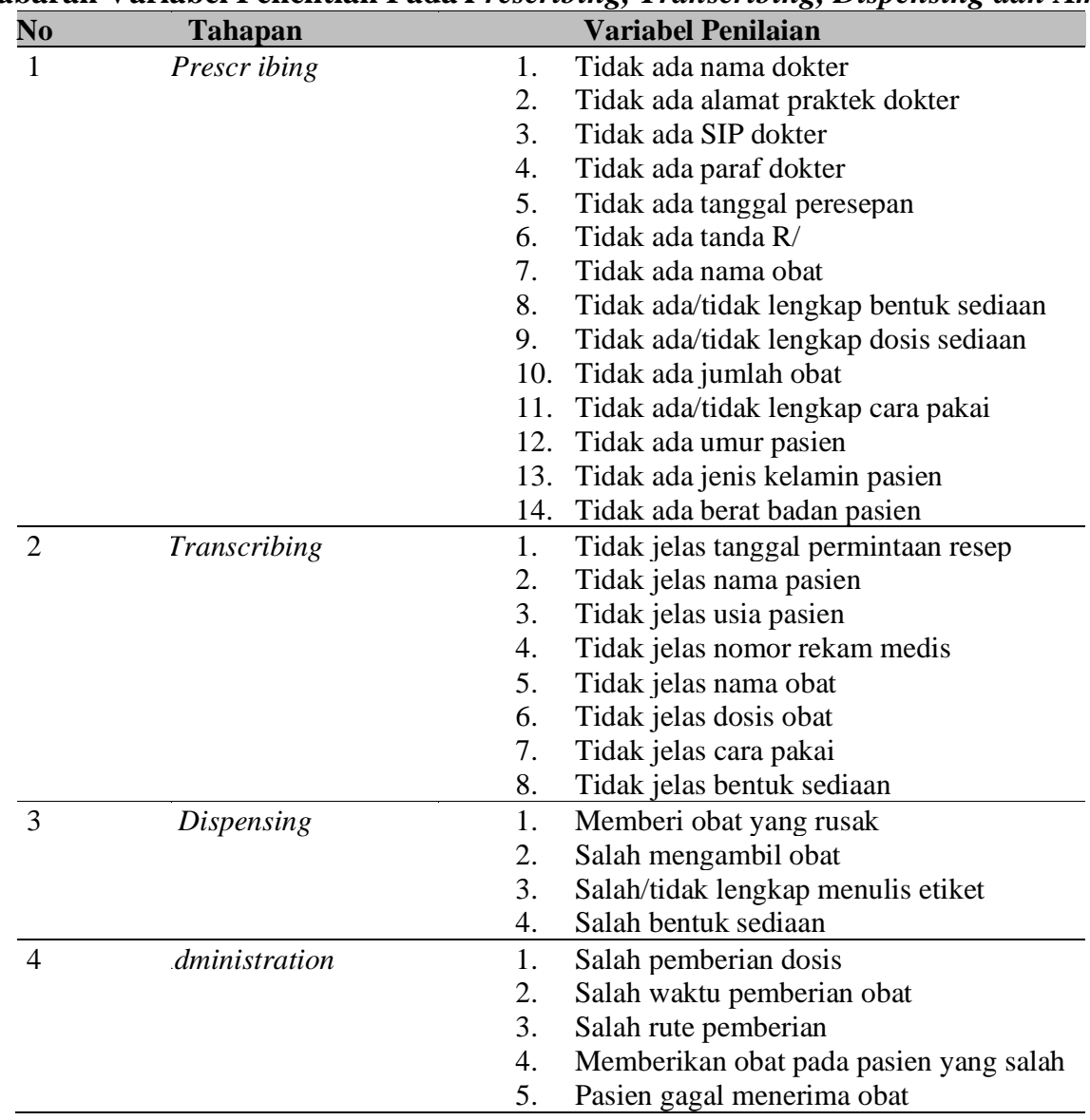

\section{Pengumpulan Data}

Data yang dikumpulkan dalam penelitian ini yaitu berupa data sekunder dengan mengumpulkan data resep bulan Maret 2020. Data dikumpulkan dan dicatat pada lembar formulir dengan dilakukan pengamatan mengenai kelengkapan fase prescribing, transcribing, dispensing, dan administration.

\section{Analisis Data}

Analisis data dilakukan secara kuantitatif dengan analisis univariat (analisis deskriptif) dan dihitung dalam besaran persentase sehingga menghasilkan angka persentase yang dimaksudkan pada masing-masing fase kejadian medication error.

\section{HASIL DAN PEMBAHASAN}

Berdasarkan penelitian yang telah dilakukan, terdapat 3405 resep rawat jalan yang masuk ke Instalasi Farmasi Rumah Sakit X Cilacap pada bulan Maret 2020. Berdasarkan perhitungan, minimal sampel yaitu sebanyak 385 lembar resep. Untuk validasi hasil penelitian, jumlah lembar resep yang digunakan dalam penelitian ini sebanyak 423 lembar resep.

1. Analisis Medication Error Tahap Prescribing

Tabel 2. Hasil Penilaian Medication error Tahap Prescribing

No PARAMETER PENILAIAN JUMLAH RESEP PERSEN (\%)




\begin{tabular}{|c|c|c|c|}
\hline 1 & Tidak ada nama dokter & 0 & $0,00 \%$ \\
\hline 2 & Tidak ada alamat praktek dokter & 0 & $0,00 \%$ \\
\hline 3 & Tidak ada SIP dokter & 336 & $79,43 \%$ \\
\hline 4 & Tidak ada paraf dokter & 352 & $83,22 \%$ \\
\hline 5 & Tidak ada tanggal peresepan & 0 & $0,00 \%$ \\
\hline 6 & Tidak ada tanda R/ & 1 & $0,24 \%$ \\
\hline 7 & Tidak ada nama obat & 0 & $0,00 \%$ \\
\hline 8 & Tidak ada/tidak lengkap bentuk sediaan obat & 375 & $88,65 \%$ \\
\hline 9 & Tidak ada/tidak lengkap dosis sediaan & 314 & $74,23 \%$ \\
\hline 10 & Tidak ada jumlah obat & 0 & $0,00 \%$ \\
\hline 11 & Tidak ada/tidak lengkap cara pakai & 3 & $0,71 \%$ \\
\hline 12 & Tidak ada umur pasien & 0 & $0,00 \%$ \\
\hline 13 & Tidak ada jenis kelamin pasien & 0 & $0,00 \%$ \\
\hline 14 & Tidak ada berat badan pasien & 423 & $100 \%$ \\
\hline
\end{tabular}

Keterangan : 0 tidak ditemukan kesalahan

Pada tahap ini dinilai berdasarkan ketidak lengkapan resep yang terdiri dari 14 komponen penilaian yaitu, tidak ada nama dokter, tidak ada alamat praktek dokter, tidak ada SIP dokter, tidak ada paraf dokter, tidak ada tanggal peresepan, tidak ada tanda R/, tidak ada nama obat, tidak ada/tidak lengkap bentuk sediaan obat, tidak ada/tidak lengkap dosis sediaan, tidak ada jumlah obat, tidak ada/tidak lengkap cara pakai, tidak ada umur pasien, tidak ada jenis kelamin pasien dan tidak ada berat badan pasien.

Pada tabel diatas diketahui bahwa tidak ada SIP dokter terjadi pada 336 lembar resep dengan angka kejadian sebesar 79,43\% dari total sampel sebanyak 423 lembar resep. Berdasarkan hasil wawancara dengan beberapa dokter yang ada di Rumah Sakit X Cilacap, tidak ada SIP dokter pada beberapa resep dikarenakan masih ada stempel yang hanya berisikan nama dokter, hal ini terjadi karena belum dibuatkan stempel yang berisikan nama dan SIP dokter.

Tidak ada paraf dokter terjadi pada 352 lembar resep dengan angka kejadian 83,22\% dari total sampel sebanyak 432 lembar resep. Faktor yang dapat menyebabkan dokter tidak menuliskan paraf pada peresepan adalah karena dokter menggunakan cap stempel sebagai pengganti identitas dokter[10]. Namun cap stampel hanya berisikan nama dan SIP dokter, dengan demikian banyak dokter yang tidak menuliskan paraf karena menganggap sudah cukup dengan adanya cap stempel.

Berdasarkan wawancara dengan beberapa dokter di rumah sakit X Cilacap, Tidak ada paraf dokter pada resep dikarenakan banyaknya pasien yang berobat sehingga ada sebagian dokter yang mencantumkan paraf tetapi tidak sesuai dengan sampel paraf yang ada di instalasi farmasi. Tidak ada tanda R/ terjadi pada 1 lembar resep dengan angka kejadian sebesar 0,24\% dari total sampel sebanyak 423 lembar resep. Tanda $\mathrm{R} /$ atau recipe pada bagian kiri resep artinya ambilah atau berikanlah. Penulisan tanda R/ pada resep memiliki fungsi sebagai kata pembuka komunikasi antara dokter penulis resep dengan apoteker[10].

Tidak ada/tidak lengkap bentuk sediaan obat terjadi pada 375 lembar resep, dengan angka kejadian sebesar $88,65 \%$, dari total sampel sebanyak 423 lembar resep. Berdasarkan wawancara dengan beberapa dokter yang bekerja di Rumah Sakit X Cilacap, tidak ada/tidak lengkap bentuk sediaan disebabkan dari kebiasaan sebagian dokter yang hanya akan menuliskan apabila obat tersebut bukan berupa bentuk sediaan tablet, dan juga dokter menganggap bahwa petugas farmasi sudah paham bentuk sediaan obat yang sering diresepkan.

Adanya bentuk sediaan sangat berpengaruh terhadap keberhasilan pengobatan pasien, karena pemilihan bentuk sediaan harus disesuaikan dengan kondisi tubuh pasien[10]. 
Tidak ada/tidak lengkap dosis sediaan terjadi pada 314 lembar resep, dengan angka kejadian sebesar 74,23\%, dari total sampel sebanyak 423. Hal ini terjadi karena dokter terbiasa tidak menuliskan dosis sediaan yang memiliki dosis terendah, dan apabila suatu obat hanya memiliki 1 macam dosis maka dokter tidak menuliskan dosis sediaannya, sehingga dokter akan menuliskannya apabila obat tersebut memiliki beragam dosis seperti amlodipine $5 \mathrm{mg}$ dan amlodipine $10 \mathrm{mg}$.

Tidak ada/tidak lengkap cara pakai terjadi pada 3 lembar resep, dengan angka kejadian sebesar $0,71 \%$ dari total sampel sebanyak 423 lembar resep. Pentingnya penulisan cara pakai pada resep berfungsi untuk keamanan dan keberhasilan penggunaan obat dan juga berfungsi supaya pada saat pelayanan tidak terjadi kesalahan informasi penggunaan obat, karena kondisi pasien menentukan aturan pakai penggunaan obat yang tepat[11]. Tidak ada berat badan pasien terjadi pada 423 lembar resep dengan angka kejadian sebesar 100\%, dari total sampel sebanyak 423 lembar resep. Berdasarkan wawancara dengan beberapa dokter yang bekerja di Rumah Sakit X Cilacap, sebagian dokter mengatakan tidak mencantumkan berat badan pasien karena dokter tidak mengetahui adanya perincian berat badan pasien pada resep sehingga dokter tidak menuliskannya, selain itu menurut sebagian dokter mengatakan, pada rekam medis sudah ada berat badan pasien sehingga dokter tidak menuliskannya.

Ada juga dokter yang mengatakan bahwa dokter akan menuliskan berat badan pasien apabila pasien tersebut adalah pasien anak-anak. Namun pada kenyataannya selama proses analisis tidak ditemukan adanya resep yang tercantum berat badan pasien dan tidak terkecuali pada resep pasien anak-anak. Pencantuman berat badan pada resep merupakan salah satu aspek penting dalam perhitungan dosis, khususnya pada perhitungan dosis anak[11].

\section{Analisis Medication Error Pada Tahap Transcribing}

Tabel 3. Hasil Penilaian Medication error Tahap Transcribing

\begin{tabular}{clcc}
\hline No & \multicolumn{1}{c}{ PARAMETER PENILAIAN } & JUMLAH RESEP & PERSEN (\%) \\
\hline 1 & Tidak jelas tanggal permintaan resep & 0 & $0,00 \%$ \\
\hline 2 & Tidak jelas nama pasien & 1 & $0,24 \%$ \\
\hline 3 & Tidak jelas usia pasien & 1 & $0,24 \%$ \\
\hline 4 & Tidak jelas nomor rekam medis & 1 & $0,24 \%$ \\
\hline 5 & Tidak jelas nama obat & 1 & $0,24 \%$ \\
\hline 6 & Tidak jelas dosis obat & 0 & $0,00 \%$ \\
\hline 7 & Tidak jelas cara pakai & 10 & $2,36 \%$ \\
\hline 8 & Tidak jelas bentuk sediaan & 375 & $88,65 \%$ \\
\hline
\end{tabular}

Keterangan : 0 tidak ditemukan kesalahan

Pada tahap ini terdapat 8 komponen penilaian yaitu tidak jelas tanggal permintaan resep, tidak jelas nama pasien, tidak jelas usia pasien, tidak jelas nama obat, tidak jelas dosis obat, tidak jelas cara pakai, tidak jelas rute pemberian, dan tidak jelas bentuk sediaan.

Tidak jelas nama pasien terjadi pada 1 lembar resep dengan angka kejadian sebesar 0,24\% dari total sampel sebanyak 423 lembar resep. Tidak jelas usia pasien terjadi pada 1 lembar resep dengan angka kejadian sebesar $0,24 \%$ dari total sampel sebanyak 423 lembar resep. Tidak jelas nomor rekam medis terjadi pada 1 lembar resep dengan angka kejadian sebesar $0,24 \%$ dari total sampel sebanyak 423 lembar resep. Tidak jelas nama obat terjadi pada 1 lembar resep dengan angka kejadian sebesar $0,24 \%$ dari total sampel sebanyak 423 lembar resep. Tidak jelas cara pakai terjadi pada 10 lembar resep sebesar 2,36\% dari total sampel sebanyak 423 lembar resep. Tidak jelas bentuk sediaan terjadi pada 375 lembar resep sebesar $88,65 \%$ dari total sampel sebanyak 423 lembar resep.

Kesalahan pada tahap transcribing ini biasanya disebabkan karena pada resep manual terdapat tulisan dokter yang tidak jelas sehingga mengakibatkan resep sulit terbaca dan pada resep yang di analisis ada beberapa resep dokter tidak secara lengkap menuliskan dosis obat dan bentuk sediaan[5]. Faktor kesalahan pada tahap ini diakibatkan karena dokter menganggap petugas farmasi sudah paham dan sudah terbiasa dengan dosis obat dan bentuk sediaan yang 
sering diresepkan[10]. Faktor kesalahan yang bisa terjadi pada tahap transcribing yaitu ketika tulisan dokter tidak terbaca, staf farmasi tidak melakukan konfirmasi ulang terhadap tulisan tersebut hal ini tidak dilakukan ulang karena staf farmasi sudah yakin dan mempunyai asumsi terhadap tulisan tersebut[8].

\section{Analisis Medication Error Pada Tahap Dispensing}

Tabel 4. Hasil Penilaian Medication error Tahap Dispensing

\begin{tabular}{clcc} 
No & PARAMETER PENILAIAN & JUMLAH RESEP & PERSEN (\%) \\
\hline 1 & Memberi obat yang rusak & 0 & $0,00 \%$ \\
\hline 2 & Salah mengambil obat & 0 & $0,00 \%$ \\
\hline 3 & Salah/tidak lengkap menulis etiket & 423 & $100 \%$ \\
\hline 4 & Salah bentuk sediaan & 0 & $0,00 \%$ \\
\hline
\end{tabular}

Keterangan : O tidak ditemukan kesalahan

Pada tahap ini terdapat 4 komponen penilaian yaitu memberi obat yang rusak, salah mengambil obat, salah/tidak lengkap menulis etiket dan salah bentuk sedian. Dari hasil analisis pada tabel 4 menunjukan bahawa pada tahap ini yang berpotensi menimbulkan medication error hanya terjadi pada 1 komponen yaitu salah/tidak lengkap menulis etiket dengan persentase $100 \%$ dari total sampel 423 lembar resep. Hal ini disebabkan karena etiket yang ditulis tidak terisi dengan lengkap seperti halnya pada bagian waktu meminum obat, pada bagian bentuk sediaan, dan tanggal kadaluarsa. Hal ini dapat berpotensi menimbulkan medication error. Pencantuman waktu meminum obat ini cukup penting karena meminum obat sesuai interval waktu yang tepat dapat membantu keefektifan terapi suatu obat.

4. Analisis Medication Error Pada Tahap Administration

Tabel 5. Hasil Penilaian Medication error Tahap Administration

\begin{tabular}{clcc}
\hline No & \multicolumn{1}{c}{ PARAMETER PENILAIAN } & JUMLAH RESEP & PERSEN (\%) \\
\hline 1 & Salah pemberian dosis & 27 & $1,28 \%$ \\
\hline 2 & Salah waktu pemberian obat & 0 & $0,00 \%$ \\
\hline 3 & Salah rute pemberian & 0 & $0,00 \%$ \\
\hline 4 & Memberikan obat pada pasien yang salah & 0 & $0,00 \%$ \\
\hline 5 & Pasien gagal menerima obat & 0 & $0,00 \%$ \\
\hline
\end{tabular}

Keterangan : 0 tidak ditemukan kesalahan

Pada tahap administration terdapat 5 komponen penilaian yaitu salah pemberian dosis, salah waktu pemberian obat, salah rute pemberian, memberikan obat pada pasien yang salah dan pasien gagal menerima obat. Berdasarkan hasil Tabel 5 tahap administration menunjukkan bahwa terjadi kesalahan pemberian dosis pada 27 lembar resep dengan angka kejadian sebesar $1,28 \%$ dari total sampel sebanyak 423 lembar resep.

Hal ini terjadi karena pada beberapa resep terdapat kesalahan dalam pemberian dosisnya. Seperti pada resep pasien lansia berumur 73 tahun yang diberikan obat simvastatin $20 \mathrm{mg}$ dengan aturan pakai 3 kali sehari. Dosis maksimum sediaan simvastatin yaitu $40 \mathrm{mg} / \mathrm{hari}$. Berdasarkan perhitungan dosis maksimal simvastatin untuk pasien tersebut yaitu sebanyak 30 $\mathrm{mg} /$ hari. Tetapi pada resep, pasien lansia tersebut diberikan dosis simvastatin sebanyak 60 $\mathrm{mg} /$ hari, maka hal tersebut tidak sesuai dengan perhitungan dosisnya, oleh karena itu dinyatakan over dosis.

Pada komponenen penilaian lain seperti salah waktu pemberian obat, salah rute pemberian, memberikan obat pada pasien yang salah, dan pasien gagal menerima obat tidak terjadi kesalahan. Pada komponen tersebut peneliti menganalisis dengan cara melihat petugas farmasi dalam memberikan informasi cara penggunaan obat atau pemberian PIO (Pelayanan Informasi Obat) kepada pasien dan melihat informasi tertulis di etiket yang sudah disesuaikan dengan aturan yang ada diresep. 
5. Hasil Kejadian Medication error Tahap Prescribing, Transcribing, Dispensing, dan Administration dengan menggunakan Diagram Batang

Tabel 6. Grafik Persentase Kejadian Medication error pada Tahap Prescribing, Transcribing, Dispensing, dan Administration

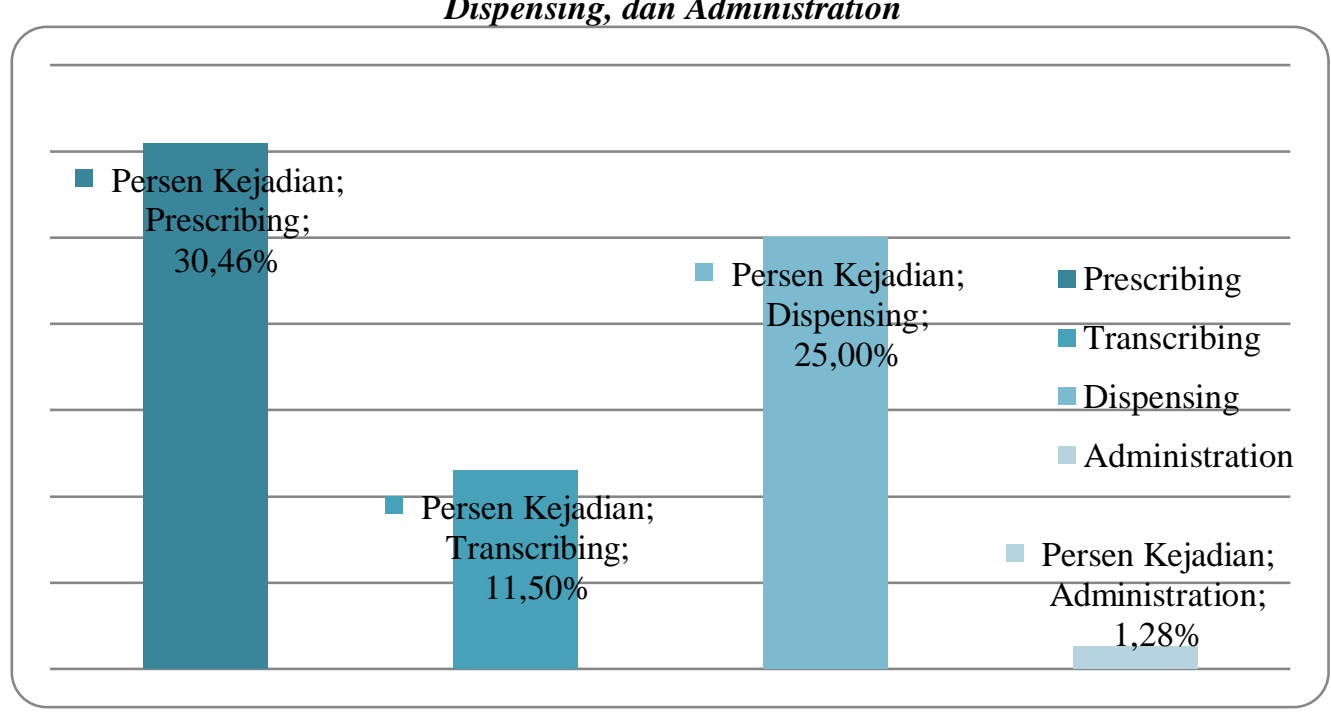

Grafik di atas menunjukan bahwa medication error pada tahap prescribing yaitu sebesar $30,46 \%$ dari total kejadian sebanyak 1804, lalu tahap transcribing sebesar 11,50\% dari total kejadian 389, kemudian tahap dispensing sebesar 25,00\% dari total kejadian 423, dan pada tahap administration sebesar 1,28\% dengan total kejadian 27.

\section{KESIMPULAN}

Dari hasil penelitian yang telah dilakukan, diketahui bahwa medication error yang terjadi pada tahap prescribing, transcribing, dispensing dan administration terhadap 423 lembar resep pasien rawat jalan yang ada di Instalasi Farmasi Rumah Sakit X Cilacap yaitu, tahap prescribing sebesar 30,46\%, tahap transcribing sebesar 11,50\%, tahap dispensing sebesar 25,00\%, dan tahap administration sebesar $1,28 \%$.

\section{DAFTAR PUSTAKA}

[1] Majdah Zawawi1 and Noriah Ramli, Peraturan Menteri Kesehatan Republik Indonesia Nomor 72 Tahun 2016 Tentang Standar Pelayanan Kefarmasian. 2016.

[2] Permenkes RI, "Peraturan Menteri Kesehatan RI No 4 Tahun 2018 tentang Kewajiban Rumah Sakit dan Kewajiban Pasien," Jakarta, 28 Maret 2018, 2018.

[3] National Coordinating Council for Medication Error Reporting and Prevention., "About Medication Errors. What is a Medication Error?," NCCMERP, 2016. .

[4] Satibi, M. Vika, S. Sri, and Kuswardhani, "Analisis Perbedaan Implementasi Standar Pelayanan Kefarmasian dengan Potensi Medication Error di Beberapa Rumah Sakit Kota Semarang," J. Manaj. dan Pelayanan Farm., 2017.

[5] H. Fajarini and A. Widodo, "EValuasi Legalitas dan Kelengkapan Admnistratif Resep Pada Rumah Sakit di Kabupaten Brebes," Parapemikir J. Ilm. Farm., vol. 9, no. 2, pp. 6167, 2020, doi: 10.30591/pjif.v.

[6] R. Septiyana, H. S. Padmanegara, and S. Larasati, "Evaluasi Kerasionalan Peresepan Obat 
Anti Diabetes Militus Oral Pada Pasien Prolanis Bpjs Di Rumah Sakit Islam Kendal,” J. Farmasetis, 2015, doi: 10.32583/FARMASETIS.V4I1.230.

[7] I. Nurhayati, T. Kurniawan, and W. Mardiah, "Perilaku Pencegahan Penularan dan FaktorFaktor yang Melatarbelakanginya pada Pasien Tuberculosis Multidrugs Resistance (TB MDR)," J. Keperawatan Padjadjaran, 2015, doi: 10.24198/jkp.v3n3.5.

[8] I. Susanti, "Identifikasi Medication Error pada fase Prescribing, Transcribing, dan Dispensing di Depo Farmasi Rawat Inap Penyakit Dalam Gedung Teratai, Isntalasi Farmasi RSUP Fatmawati Periode 2013," Repos. UIN, 2015.

[9] A. puji hastuti and heny nurma yunita, "Pengaruh Penerapan Pencegahan Medication Error Terhadap Perilaku Perawat Tentang Tujuh Benar Pemberian Obat Di Rsui Kabupaten Malang," J. Kesehat. Hesti Wira Sakti, 2017.

[10] M. A. W. Khairurrijal and N. A. Putriana, "Review: Medication Erorr Pada Tahap Prescribing, Transcribing, Dispensing, dan Administration," Farmasetika.com (Online), 2018, doi: 10.24198/farmasetika.v2i4.15020.

[11] P. Nilasari, D. Hasan, and W. U. H, "Faktor-Faktor yang Berkaitan / Berhubungan Dengan Mediation Error dan Pengaruhnya Terhadap Patient Safety yang Rawat Inap di RS. Pondok Indah Jakarta Tahun 2012-2015," Soc. Clin. Pharm. Indones. J. Univ. 17 Agustus 1945 Jakarta, vol. 2, no. 1, pp. 1-9, 2017, [Online]. Available: http://journal.uta45jakarta.ac.id/index.php/SCPIJ/article/view/919/626. 